https:/ / doi.org/10.18485/iipe_nsail.2020.ch3

Miloš JONČIĆ ${ }^{1}$

\title{
NEDRŽAVNI AKTERI U MEĐUNARODNOM HUMANITARNOM PRAVU
}

Apstrakt: Postojanje nedržavnih aktera kao subjekata u međunarodnim odnosima i kao strane u oružanim sukobima, imaju sve veći uticaj u međunarodnoj zajednici i na polju međunarodnog prava. Najčešće pitanje koje se nameće sa stanovišta doktrine i prakse međunarodnog prava tiče se njihovog statusa, preciznije njihovih međunarodnih prava i obaveza, odgovornosti za kršenje normi međunarodnog javnog prava, a posebno međunarodnog prava oružanih sukoba (međunarodnog humanitarnog prava). Na ovaj način se otvara pitanje oko priznavanja njihovog pravnog subjektiviteta. Predmet istraživanja je da li, u kojoj meri i po kom pravnom osnovu se norme međunarodnog humanitarnog prava primenjuju, $\mathrm{tj}$. obavezuju nedržavne aktere. Kako nedržavni akteri (uslovno nedržavni entiteti) ne mogu formalno da postanu strana $u$ međunarodnim ugovorima koji regulišu zaštitu u oružanim sukobima, razmatra se pitanje alternativnih mehanizama sa kojima ovi akteri mogu da izraze svoj pristanak i da se obavežu na poštovanje normi međunarodnog prava uopšte, a posebno međunarodnog humanitarnog prava. Svaki od ovih alternativnih mehanizama pruža mogućnost za utvrđivanje odgovornosti za kršenje pravila međunarodnog prava. Rad analizira upravo pojam i pravni položaj nedržavnih aktera kao učesnika u oružanim sukobima. Nedržavni entiteti mogu biti učesnici u nemeđunarodnom oružanom

\footnotetext{
${ }^{1}$ Dr Miloš Jončić, naučni saradnik, Institut za međunarodnu politiku i privredu, e-mail: mjoncic@diplomacy.bg.ac.rs;

Rad je nastao u okviru naučnoistraživačkog projekta "Srbija i izazovi u međunarodnim odnosima 2020. godine“ nauke i tehnološkog razvoja Republike Srbije, a realizuje Institut za međunarodnu politiku i privredu tokom 2020. godine.
} 
sukobu, ali je izmenjeni karakter oružanih sukoba krajem XX i početkom XXI veka izbrisao jasnu granicu između međunarodnih i nemeđunarodnih oružanih sukoba, i ostavio nedoumicu da li nedržavni entiteti mogu biti strana u oružanim sukobima čiji se karakter može okarakterisati kao mešoviti ili inernacionalizovani. Cilj rada je da na osnovu istraživanja izmenjenog karaktera oružanih sukoba, i položaja nedržavnih aktera i entiteta u njima, dođe do relevantnih odgovora vezanih za nedržavne entitete $\mathrm{i}$ aktere $\mathrm{u}$ međunarodnom pravu. Poseban problem predstavlja činjenica da neki nedržavni akteri kao učesnici u oružanom sukobu nemaju status legalnog učesnika, što znatno komplikuje primenu međunarodnopravnih normi.

Ključne reči: nedržavni akteri, nedržavni entiteti, oružani sukobi, legalni učesnici u oružanom sukobu, međunarodno pravo oružanih sukoba

\section{POJAM NEDRŽAVNIH AKTERA I NEDRŽAVNIH ENTITETA U MEĐUNARODNOM HUMANITARNOM PRAVU}

U međunarodnom pravu došlo je do vertikalnog pomeranja gde države jesu ostali važni subjekti, ali ne i jedini. ${ }^{2}$

Primena normi međunarodnog humanitarnog prava na nedržavne aktere predstavljaju "mračnu šumu“ u kojoj se međunarodno humanitarno pravo ponekad bori da nametne kontrolu i razmotri neke od razloga zašto su primenljivost i pogodnost normi dovedeni u pitanje.

Kako bi definisali pojam nedržavnih akata i utvrdili njihov položaj u oružanim sukobima neophodno je odrediti u kojim će sukobima biti sagledan njihov položaj. Ratovi ili oružani sukobi postojali su kroz čitavu istoriju i u skladu sa tim bili su predmet razmišljanja i pisanja mnogih teoretičara. Tako je Klauzevic (Karl Filip Gotfrid fon Klauzevic) rat definisao kao državnu politiku nastavljenu drugim sredstvima, nasilnim sredstvima. ${ }^{3}$ Ovakva definicija opravdava tvrdnju da je rat istovremeno i politički akt, odnosno politički motivisan akt. U situacijama kada druga sredstva nisu dovoljna kako bi se postigli unapred definisani politički

${ }^{2}$ Džozef S. Naj, Jr., Kako razumevati međunarodne sukobe, Stubovi kulture, Beograd, 2006, str. 16-17.

${ }^{3}$ Karl fon Klauzevic, O ratu, VIZ, Beograd, 1951, str. 53. 
ciljevi, tada se pribegava ratu. ${ }^{4}$ Ratovi, odnosno oružani sukobi, a pre svega napadački predstavljaju produkt političkih interesa države koja njime nastoji da ih realizuje, a ti politički interesi u pozadini uvek imaju i ekonomske interese. ${ }^{5}$ Tezu da je - rat kompleksan međusobni odnos između strana u sukobu, koji je nastao voljom jedne strane (ili obe), ona (one su) je tu volju jasno iskazala kroz preduzimanje akata koji se mogu okarakterisati kao oružana akcija -izneo je Gavro Perazić. Ti akti su od značaja za međunarodno pravo i mogu se okarakterisati kao agresija, oružana intervencija ili oružana represalija. Upravo prema tim aktima može da se okarakteriše da li je neka država prekršila međunarodno pravo ili ne. ${ }^{6}$ Ovi akti su od presudnog značaja da bi neki akt primene sile okarakterisali kao oružani sukob. Jer ne predstavlja svaki akt nasilja ujedno i oružani sukob. Tako, neki autori definišu "rat je stanje borbe među državama - status per vim certantium “ ili „rat je samo ona borba koja se vodi među državama - publicorum armorum justa contentium ${ }^{\text {"7 }}$ Neki rat definišu kao „prepirku između dve ili više država kroz njihove oružane snage (armije), u cilju da nadvladaju jedna drugu i nametnu takve uslove za zaključenje mira koje odgovaraju pobedničkoj strani“".

Države često vole da negiraju da su u "ratu“ i oružane sukobe nazivali drugačije kako ne bi bile okrivljene za kršenje međunarodnog prava. ${ }^{9}$ Neke države su na ovaj način opravdavale i agresiju na Saveznu Republiku Jugoslaviju 1999. godine. Navodeći izjave tadašnjeg

${ }^{4}$ Zoran Vučinić, Međunarodno ratno i humanitarno pravo, Službeni glasnik, Beograd, 2006, str. 53.

${ }^{5}$ Ibid.

${ }^{6}$ Gavro Perazić, Međunarodno ratno pravo, Beograd, 1987; Zoran Vučinić, Međunarodno ratno i humanitarno pravo, Vojnoizdavački zavod, Beograd, 2001).

${ }^{7}$ Zoran Radivojević, Vesna Knežević Predić, „Prag primene međunarodnog humanitarnog prava“, Teme, g. XXXVII Br. 1, januar-mart 2013, Niš, str. 383-403.

${ }^{8}$ Oppenheim L., International Law, War and Neutrality, 7th edn, ed. H. Lauterpacht, London, 1952, p. 202.

${ }^{9}$ Tako je Ujedinjeno Kraljevstvo u Korejskom ratu podvuklo da nisu angažovani u ratu, već u akciji snaga Ujedinjenih nacija kako bi se zakonito suprotstavili agresiji na osnovu Povelje Ujedinjenih nacija, Ingrid Detter, The Law of War, Cambridge University Press, 2nd ed., 2000. p. 5. 
državnog rukovodstva država uključenih u agresiju na SRJ, može se videti da sve koriste druge nazive želeći da umanje značaj tog protivpravnog akta, ali i da istaknu svoju potrebu da sankcionišu one koji se ne uklapaju u njihov koncept međunarodne zajednice. Tako je tadašnji britanski ministar spoljnih poslova Robin Kuk (Robin Cook) izjavio da je reč o „,...akciji koja treba da prisili tu državu da prestane sa etničkim čišćenjem Albanaca na Kosovu...". Takođe, zvanični stav Velike Britanije je da tada nije bilo ratnog stanja „....već samo snažne vojne akcije tokom intervencije na Kosovu.... ${ }^{10}$

Ono što ovde treba istaći jeste da svaki rat jeste oružani sukob, ali svaki oružani sukob nije rat. ${ }^{11}$

Podela na međunarodne i nemeđunarodne (unutrašnje) oružane sukobe izvršena je početkom XIX veka, ali pravila koja regulišu sukobe datiraju iz perioda starog veka. U savremenoj doktrini međunarodnog prava, odnosno, međunarodnog prava oružanih sukoba (međunarodnog humanitarnog prava) iskristalisalo se shvatanje o istorijskoj genezi međunarodnog prava koje upućuje da koreni humanitarnog prava leže daleko u prošlosti. ${ }^{12}$ Teba ukazati na činjenicu

${ }^{10}$ Ingrid Detter, The Law of War, op. cit., Cambridge University Press, 2nd ed., 2000. p. 8.

${ }^{11}$ Vladan Jončić: „Promene u međunarodnim odnosima i u politici primene sile i njihov uticaj na karakter oružanih sukoba i međunarodno pravo oružanih sukoba", Pravni život, Udruženje pravnika Srbije, br. 12. Tom IV, Beograd, 2014, str. 178.

${ }^{12}$ Boris Krivokapić, Mir i rat, Institut za uporedno pravo, Poslovni i pravni fakultet, Beograd, 2017, str. 72-76, 540-547; Vladan Jončić, Ratni zarobljenici međunarodnopravni status, VIZ, 2003, str. 9-55; Boris Krivokapić, Međunarodno javno pravo, Poslovni i pravni fakultet, Institut za uporedno pravo, Beograd, 2017, str. 46-59; Boris Krivokapić, op. cit., 2006; Boris Krivokapić, „O nauci međunarodnog prava u antičkom svetu“, Pravni život, 12/2013, str. 215; Milan Bartoš, Međunarodno javno pravo, knj. I, Beograd, 1954, str. 65; Vladan Jončić, Međunarodno humanitarno pravo, Beograd, 2015, str. 8; Milenko Kreća, Međunarodno javno pravo, Beograd, 2010, str. 50-65; Meron, Theodor, War Crimes Law Cimes of Age, Oxford University Press Inc., New York,2012; Rhine Charls, S., International Law, Washington, 1971, pp. 9-13; G. I. Tunkin, Meždunarodnoe pravo, Moskva, 1982, str. 14-15; Georg Schwarczenberger, International, Law, the Law of armed conflictt, 1957; Juraj Andrassy, Božidar Bakotić, Budislav Vukas, Međunarodno pravo, Zagreb, 1989, str. 46-47; Vladimir-ĐuroDegan, Međunarodno pravo, Rijeka, 2000, str. 33-35. 
da se tek krajem XIX i početkom XX veka javlja potreba za razlikovanjem međunarodnih i unutrašnjih sukoba.

Cilj podele na unutrašnje i međunarodne oružane sukobe bio je da se ukaže da se norme međunarodnog ratnog prava prvenstveno primenjuju u međunarodnim oružanim sukobima. ${ }^{13}$ Stanovište doktrine je bilo da se međunarodno pravo ne može primenjivati u unutrašnjim pobunama i građanskim ratovima. Tvrdnja je zasnovana na čvrstom shvatanju suvereniteta država i principu potpune zabrane mešanja $u$ unutrašnje stvari država. ${ }^{14}$

U klasičnom međunarodnom pravu razlikovala su se tri nivoa primene sile usmerene protiv državne vlasti. ${ }^{15}$ Razlika među primenama sile se vezivala za obim i intezitet sukoba (borbenih operacija). U inostranoj literaturi se koriste tri različita izraza za različite oblike primene sile: rebellion, insurgency i belligerency. ${ }^{16}$ Rebellion predstavlja skroman, sporadičan izazov dela populacije koja je nameravala da dobije kontrolu nad delom teritorije. Pod uslovom da se ustanak može brzo i efikasno rešiti u okvirima unutrašnjih bezbednosnih mera, sukob bi ostao potpuno unutrašnji. Pobunjenici u ovom slučaju nisu imali nikakvu zaštitu međunarodnih normi i potpadali su pod sankcije unutrašnjeg pravnog poretka. Insurgency, s druge strane, odnosi se na značajniji napad na legitimni državni poredak, uz koji pobunjeničke frakcije imaju takav stepen organizovanosti da značajno mogu da ugroze kredibilitet vlade. Na ovom stepenu država na čijoj teritoriji se odvija pobuna i dalje osporava postojanje pobunjenika, dok strane države već prepoznaju pobunjenike i ne smatraju ih više pukim prekršiocima zakona i javljaju

${ }^{13}$ Vladan Jončić: „Pravni smisao oružanih sukoba u procesu evropskih integracija“, Srpska politička misao, Institut za političke studije, No. 1/2015, Vol. 47, Beograd, 2015, str. 193-207.

${ }^{14}$ Miloš Jončić, „Savremene tendencije u razvoju međunarodnog humanitarnog prava“", Savremeni međunarodni ekonomski i pravni poredak, ur. Sanja Jelisavac Trošić, Institut za međunarodnu politiku i privredu, Beograd, 2016, str. 260

${ }^{15}$ Lindsay Moir, The Law of Internal Armed Conflict, Cambridge University Press, Cambrige, 2004, p. 4.

${ }^{16}$ Ibid. 
se prva uspostavljanja odnosa sa pobunjenicima. ${ }^{17} \mathrm{Na}$ ovom nivou se već otvara pitanje primene normi međunarodnog humanitarnog prava. Prepoznavanje pobunjenika kao sukobljene strane ne donosi nikakav formalni status, ali uvodi neka prava i obaveze za obe strane.

Kako bi neki sukob iz zategnutosti i nemira, u kojima se ne primenjuje međunarodno pravo, prerastao u oružani sukob potrebno je ispunjenje određenih kriterijuma koji se odnose na intenzitet oružanih akcija, obim angažovanja vojnih snaga, trajanje preduzetih akata i njihov teritorijalni opseg. Potrebno je da nedržavne oružane grupe, kako bi stekle status ustanika (pobunjenika), imaju odgovornu komandu i da ta komanda vrši konstantnu kontrolu nad snagama koje izvode vojne operacije i da drže pod kontrolom teritoriju koja im omogućava vođenje neprekidnih i usmerenih vojnih operacija. ${ }^{18}$ Ciljevi ovakvih sukoba su najčešće promena postojećeg političkog sistema, secesionizam, tj. odvajanje jednog dela teritorije i drugo. ${ }^{19}$

Važnost razlikovanja dolazi do izražaja jer unutrašnji sukobi mogu biti posledica indirektne agresije. Zato je pod pojmom agresije i navedeno ubacivanje oružanih bandi, grupe/a najamnika s ciljem da izvrše akte oružanog nasilja i izazovu nerede ili pobunu. Kraj XX i početak XXI veka doneo je nove oblike primene sile u međunarodnim odnosima. Doktrina još nije dala konačnu ocenu da li je došlo do pojave

17 Ibid.

${ }^{18}$ Martin Van Creveld, The Transformation of War, The Free Press, New York, 1991; Vladan Jončić, Međunarodnopravni status učesnika oružanih sukoba, Pravni fakultet, Beograd, 2012, str.118-129; Ben Aston, "Critically assess Kaldor's assertion that new wars have to be understood in the context of the process known as globalization", Global Politics \& Violence, http://opendemocracy.net/debates / article-2-103-2294.jsp.benaston.com/.../Critically\%20assess\%20Kaldors; Michael Smith, "Guerillas in the mist: reassessing strategy and low intensity warfare", Review of International Studies, 2003, pp. 35-37.

${ }^{19}$ Vladan Jončić; "Promene u međunarodnim odnosima i u politici primene sile“, Pravni život, br. 12, tom IV, Udruženje pravnika Srbije, Beograd, 2014, str. 169-182; Finn Seyersted, United Nations Forces in the Law of Peace and War, Leyden, 1966, pp. 299-304; Blix, H., “Contemporary Aspects of Recognition”, 130 Recueil des cours, 1970, Vol. II, pp. 615-619. 
novih oružanih sukoba, ili su dosadašnji postojeći oblici pretrpeli korekcije i izmene. ${ }^{20}$

U unutrašnjim sukobima u kojima najviše učestvuju nedržavni akteri, suprotno međunarodnim u kojima je reč o odnosu između suverenih država, odnos sukobljenih strana je odnos između države i njenih državljana. ${ }^{21}$ Iz tog razloga se u ovim sukobima ističe da ovde ne postoji dilema oko humanosti i vojne potrebe već između humanosti i suvereniteta. ${ }^{22}$ Ovo je osnov zašto pitanje regulisanja nedržavnih oružanih aktera izaziva kontroverze. Punopravno priznavanje ovih nedržavnih aktera kao legalnih učesnika u oružanom sukobu otvara pitanje nepoštovanja načela suverenosti.

Porast unutar-državnih ratova nije puka slučajnost već posledica usložnjavanja broja i vrste subjekata u okviru međunarodnih odnosa. ${ }^{23}$

Svaki građanski rat, tj. unutrašnji sukob, može da preraste $u$ međudržavni sukob, odnosno da prevaziđe granice dotične države. ${ }^{24}$ Ovakv oblik sukoba $\mathrm{u}$ doktrini i praksi međunarodnih tribunala je okarakterisan i svrstan u grupu internacionalizovanih oružanih sukoba. Internaconalizovani oružani sukob počinje kao unutrašnji na teritoriji samo jedne države, ali potom zbog uključivanja druge države na strani pobunjenika gube unutrašnji i dobijaju međunarodni karakter. ${ }^{25}$

${ }^{20}$ Miloš Jončić, „Savremene tendencije u razvoju međunarodnog humanitarnog prava", op. cit., str. 262.

${ }^{21}$ Konstantin Obradović, (ured.), Humanitarno pravo: savremena teorija i praksa", Beogradski centar za ljudska prava, Beograd, 1997, str. 243.

${ }^{22}$ Ibid., str. 244.

${ }^{23}$ Stefan Radojković, „Nedržavni akteri i praksa zagovaranja nezavisnosti - slučaj Kosova od 1999. do 2008. godine", Godišnjak Fakultet Političkih Nauka, Beograd, Jun 2016, Vol. 10 Issue 15, str. 135-160. str. 137.

${ }^{24}$ Kako bi ukazali da se prerastanje unutrašnjeg sukoba u međunarodni nije javilo u poslednje vreme navešćemo jedan od prvih sukoba koji je prevazišao granice unutrašnje države. Takav je bio sukob između Etiopije i Somalije (1977-1978). Sukob je najpre počeo na teritoriji etiopijske pokrajine Ogaden između vojske te države i pobunjenika somalijskog porekla, a prerastao je u sukob regularnih vojski Etiopije i Somalije. Rat je okončan vojnom pobedom Etiopije.

${ }^{25}$ Zoran Radivojević, Vesna Knežević Predić, „Prag primene međunarodnog humanitarnog prava“, Teme, g. XXXVII Br. 1, januar-mart 2013, Niš, str. 397. 
Utvrđivanje internacionalizacije se vrši preko nekoliko testova, od kojih je prvi utvrđivanje da li je došlo da uključivanje druge države u sukob upućivanjem svojih oružanih snaga na teritoriju države na kojoj već postoji oružani sukob. ${ }^{26}$ Internacionalizacija se može utvrditi i putem drugog testa, koji utvrđuje da li i od kog momenta neki od učesnika u unutrašnjem sukobu počinje da deluje u interesu i u ime druge države, dakle nije reč o direktnom već indirektnom mešanju druge države. ${ }^{27}$ Kada je reč o mešovitim sukobima činjenična i pravna slika izgledala bi ovako: a) između vlade i pobunjenika primenjuje se pravo koje se odnosi na nemeđunarodne oružane sukobe (član 3 Ženevskih konvencija i Protokol II); b) između vlade i treće države koja interveniše na strani pobunjenika počinje da se primenjuje pravo koje se odnosi na međunarodne oružane sukobe; v) između treće države koja interveniše na strani vlade i pobunjenika primenjuje se pravo merodavno za nemeđunarodne oružane sukobe; g) između trećih država koje intervenišu na obe strane mora se poštovati pravo koje važi u međunarodnim oružanim sukobima. ${ }^{28}$

$\mathrm{Na}$ konferenciji u Berlinu, gde je tom prilikom doneta Berlinska deklaracija 1999. godine, istaknuto je da se pod slučajevima „oružanih sukoba u kojima učestvuju nedržavni entiteti“ obuhvata nekoliko situacija:

1. Oružane sukobe koji nemaju međunarodni karakter u smislu zajedničkog člana 3 Ženevskih konvencija i Protokola II, dakle sukobi između vladinih snaga i nedržavnih entiteta, ili oružani sukobi između nedržavnih entiteta međusobno;

2. Sukobi u kojima interveniše jedna ili više stranih država, dakle mešoviti sukobi;

3. Sukobi koji nemaju međunarodni karakter, eventualno mešoviti sukobi, u kojima intervenišu snage Ujedinjenih nacija (UN);

4. Narodnooslobodilački ratovi u smislu člana 1 par. 4 Protokola I Ženevske konvencije. ${ }^{29}$

${ }^{26}$ Ibid.

27 Ibid.

${ }^{28}$ Ibid.

${ }^{29}$ Yearbook of the Institut of International Law, 68-I, 1999, p. 261.; Vladan Jončić, „Značaj Berlinske rezolucije o primeni međunarodnog humanitarnog prava $u$ 
Nakon Drugog svetskog rata počinje primena međunarodnog humanitarnog prava u unutrašnjim sukobima. Razlog izostanka te primene do tada leži $u$ činjenici da su unutrašnji sukobi smatrani unutrašnjom stvari države i kao takvi bili sastavni deo nepovredivog suvereniteta svake države. Antikolonijalni i nacionalnooslobodilački ratovi, vođeni u velikom broju posle Drugog svetskog rata, uticali su da se promeni shvatanje o suverenitetu država uporedo sa saznanjem da je neophodno razmotriti i pitanje primene međunarodnog prava na osnovama opštih principa zaštite ljudskih prava $u$ vanrednim okolnostima. $^{30}$

Oružani sukobi na kraju XX i na početku XXI veka doneli su nove oblike primene sile, ali i učešće novih aktera u oružanim sukobima. Neki nedržavni akteri uzimaju sve ozbiljnije učešće u oružanim sukobima. Različitost nedržavnih aktera nosi i različito učešće $u$ oružanim sukobima. Ovi akteri se mogu naći na različitim nivoima u oružanim sukobima od organizatora, savetnika sve do samih izvršilaca.

Komitet za proučavanje nedržavnih aktera Udruženja za međunarodno pravo (International Law Association) (u taljem tekstu Komitet za NDA) u periodu od 2008. do 2018. sproveo je istraživanje i realizovao projekat $\mathrm{u}$ okviru $\mathrm{kog}$ su uspostavili temelj za dalje proučavanje nedržavnih aktera. Za potrebe ovog projekta Komitet je izradio jednu radnu definiciju. Radna definicija "nedržavnog aktera“ sadrži tri elementa. ${ }^{31}$

Prvo, izričito isključuje bilo koje telo sastavljeno, kontrolisano ili upravljano od strane država ili grupa država, kao što su međunarodne organizacije i grupe država, kao što je "Grupa 7" i slična grupna tela.

oružanim sukobima u kojima učestvuju nedržavni entiteti“, Pravni život, Udruženje pravnika Srbije, Beograd, 2013, br. 12, knj. 566, str. 175-196.

${ }^{30}$ Vladan, Jončić, ,Značaj Berlinske rezolucije o primeni međunarodnog humanitarnog prava u oružanim sukobima u kojima učestvuju nedržavni entiteti“ , Pravni život, Udruženje pravnika Srbije, Beograd, 2013, knj.12, 566, str. 175-196.

${ }^{31}$ First Report of The Committee, Non-State Actors In International Law: Aims, Approach and Scope of Project and Legal Issues, International Law Association, The Hague Conference (2010), International Law Association Reports on Conferences. 
Takođe, isključuje federalne jedinice država, kao i teritorijalne entitete, npr. Kosovo i Palestina. Takve entitete Komitet je isključio s obzirom na to da ih opterećuje pitanje da li su to države ili sastavni delovi država, a ne da li su nedržavni akteri ili ne. ${ }^{32}$

Drugo, Komitet za NDA da bi definisao nedržavne aktere razmatra koje su to aktivnosti i šta rade ti akteri. Zapravo, posmatraju one aktere koji obavljajući svoje funkcije na međunarodnoj sceni imaju stvarni ili potencijalni efekat na međunarodno pravo. ${ }^{33}$

Treće, definicija Komiteta za NDA posebno navodi kategorije međunarodnopravno priznatih i organizovanih entiteta koji su uključeni, i sa druge strane koji su isključeni iz definicije. Prvenstveno pojedinci su isključeni jer ne predstavljaju "organizovane entitete“ ${ }^{34}$

Vrste aktera izričito isključenih iz izveštaja Komiteta za NDA su:

1. Međunarodne organizacije čije su članice isključivo države (npr. Svetska zdravstvena organizacija, Svetska banka, Svetska trgovinska organizacija itd.), zatim federalne jedinice država kao i „kvazipseudo" države (npr. Kosovo, Palestina);

2. Pojedinci, uključujući između ostalog i kriminalce, poput pirata;

3. Nelegalna i nelegitimna organizovana tela poput mafije, $i$

4. Ilegalna tela koja nisu organizovana na bilo koji priznat i legalan način (npr. Al-Kaida, gusarske grupe). ${ }^{35}$

U istraživanje Komiteta uključeno je sledećih pet kategorija aktera, te se može zaključiti da su to akteri koje Komitet prihvata kao nedržavne aktere $\mathrm{u}$ smislu međunarodnog prava:

32 Ibid.

33 Ibid.

${ }^{34}$ Jedan važniji razlog zašto su pojedinci isključeni iz ove definicije jeste da bi se izbeglo dupliranje, jer postoje i drugi odbori Udruženja za međunarodno pravo koji se izričito bave pitanjima koja se tiču pojedinaca $u$ međunarodnom pravu, uključujući Međunarodni odbor za ljudska prava, Odbor za interno raseljena lica i Odbor za međunarodni krivični sud.

${ }^{35}$ First Report of The Committee, Non-State Actors In International Law: Aims, Approach and Scope of Project and Legal Issues, International Law Association, The Hague Conference (2010), International Law Association Reports on Conferences. 
1. Nevladine organizacije (NVO) sa nekim oblikom priznatog međunarodnog pravnog statusa, uključujući, između ostalog, formalnu akreditaciju i neformalne odnose sa UN i telima UN koji učestvuju na konferencijama UN na kojima se usvajaju i donose pravni propisi i vrši kodifikacija prava, i nevladinih organizacija i konferencije ili skupovi strana koji su stvoreni multilateralnim sporazumima o životnoj sredini i drugim ugovorima i učešće organizovanih grupa domorodačkih naroda $\mathrm{u}$ međunarodnim institucijama;

2. Multinacionalna (poslovna) preduzeća, poznata i kao transnacionalne korporacije i "privatni sektor" u okviru UN, uključujući, inter alia, multinacionalne korporacije, određene kompanije korporativnih agenata i privatne kompanije za obezbeđenje, kao i pravna i fizička lica koja ispunjavaju uslove za "strane investitore";

3. Organizovane oružane opozicione grupe, pobunjeničke grupe, sva tri nivoa organizovanosti (rebel groups, insurgents and belligerent groups), kao i strane u unutrašnjem sukobu koje ispunjavaju uslove da se na njih mogu primeniti pravila međunarodnog humanitarnog prava i njegovih ograničenja, kao što je to slučaj sa zajedničkim članom 3 Ženevskih konvencija, uključujući, između ostalog, Eritrejski narodni Oslobodilački front, Sudanski narodnooslobodilački pokret/armiju, sa relevantnim osvrtom na istorijske primere nacionalnih oslobodilačkih grupa kao što su bivša Oslobodilačka organizacija Palestine (PLO), Afrički nacionalni kongres (ANC) i Narodna organizacija jugoistočne Afrike (SWAPO);

4. Takozvani sui generis ili jedinstveni entiteti, poput Međunarodnog komiteta Crvenog krsta, Svete stolice, Suvereni Malteški vojni red, i

5. Organizovane grupe domorodačkih naroda. ${ }^{36}$

Neki autori u nedržavne aktere svrstavaju "pored međuvladinih organizacija poput Ujedinjenih nacija (UN), tu su multinacionalne korporacije, razne nevladine organizacije, terorističke grupe i naravno, transnacionalne etničke grupe - Kurdi, Palestinci, Albanci, Jermeni, Hutsi, da navedemo samo

${ }^{36}$ Ibid. 
nekoliko. “37 Određeni broj pomenutih etničkih grupa je u procesu stvaranja svoje države, uglavnom nepriznatih u okviru UN Somaliland, Nagorno-Karabah, Abhazija, Tajvan, Zapadna Sahara, Pridnjestrovlje i Kosovo. ${ }^{38}$

U pravnoj doktrini je prihvaćeno da neki nedržavni akteri uživaju prava, dužnosti, obaveze, ali i da predstavljaju međunarodnopravnu ličnost po međunarodnom pravu. ${ }^{39} \mathrm{Ti}$ akteri se razlikuju od država, ali važno je proceniti oblik ličnosti koju uživaju kako bi razumeli njihovu promenljivu pravnu prirodu. ${ }^{40}$ Poteškoća je u tome što, pored država, ne postoji jasan zakon koji bi označavao međunarodnu pravnu ličnost. ${ }^{41}$ Većina autora se slaže da je međunarodno pravno lice entitet sa određenim kapacitetom za međunarodna prava i obaveze..$^{42} \mathrm{Neki}$ autori prihvataju manje zahtevni pristup za definisanje ovog kapaciteta pa se zadovoljavaju mogućnošću da ti entiteti samo uživaju međunarodna prava i obaveze, dok drugi zahtevaju veći stepen kapaciteta pravne ličnosti pa traže da ti entiteti imaju sposobnost zaključivanja međunarodnih sporazuma, uspostavljanja diplomatskih odnosa (aktivna i pasivna legitimacija), kao i da iznose međunarodne zahteve. ${ }^{43}$

Nedržavni akteri u oružanom sukobu, odnosno nedržavne oružane grupe (Non-State Armed Groups) su grupe koje: imaju potencijal da koriste

${ }^{37}$ Stefan Radojković, „Nedržavni akteri i praksa zagovaranja nezavisnosti - slučaj Kosova od 1999. do 2008. godine“, op. cit., str. 137.

${ }^{38}$ Stefan Radojković, „Nedržavni akteri i praksa zagovaranja nezavisnosti - slučaj Kosova od 1999. do 2008. godine“", op. cit., str. 137.

${ }^{39}$ William T. Worster, "Relative International Legal Personality of Non-State Actors", 42 Brooklyn Journal of International Law (2016). p. 207, Available at: https://brooklynworks.brooklaw.edu/bjil/vol42/iss1/4

${ }^{40}$ Ibid.

${ }^{41}$ Roland Portmann, Legal Personality in International Law (Cambridge Studies in International and Comparative Law), Cambridge University Press, Cambridge, 2010, pp. 42-79.

${ }^{42}$ William T. Worster, "Relative International Legal Personality of Non-State Actors", op. cit., p. 207, Available at: https:/ / brooklynworks.brooklaw.edu/bjil/ vol42/iss1/4

${ }^{43}$ Ibid., pp. 345, 358-359. 
oružje i upotrebljavaju silu za postizanje političkih, ideoloških ili ekonomskih ciljeva, a da pritom ne spadaju u formalne vojne strukture država, saveza država ili međunarodnih vladinih organizacija i da nisu pod kontrolom države/a na čijoj teritoriji deluju. ${ }^{44}$ Ova definicija je data za potrebe "Uputstva za humanitarne pregovore sa oružanim grupama“ (Guidelines on Humanitarian Negotiations With Armed Groups).

Funkcionalistička teorija može da bude polazna osnova za procenu koji nedržavni akteri uživaju ograničenu međunarodnu pravnu ličnost, a samim tim i da li imaju sposobnost za međunarodna prava i obaveze..$^{45}$

Iako, s jedne strane, konzervativni autori insistiraju na tome da su jedini pravi subjekti međunarodnog prava države, s druge strane postoji značajan broj autora koji podržava ideju da nedržavni akteri uživaju položaj međunarodnih pravnih lica. ${ }^{46}$

Nedržavni akteri kao međunarodna pravna lica poseduju neku vrstu nedržavnog subjektiviteta u međunarodnom pravnom sistemu, ali se taj subjektivitet bazira isključivo na njihovom delovanju na međunarodnom pravu. Dakle, nemaju subjektivitet kakav poseduju države (koje svoj subjektivitet izvlače iz spoja tri elementa - teritorija, stanovništvno, vlast) ili međunarodne organizacije (iz prenosa državnog suvereniteta na njih).

Nedržavni akteri mogu se definisati kao bilo koji akter osim suverene države, uključujući NVO, pa čak i pojedince koji su uključeni u međunarodne odnose. ${ }^{47}$ Generalno gledano, pravni položaj nedržavnih aktera je regulisan zakonodavstvom svake države pojedinačno. ${ }^{48}$

${ }^{44}$ Gerard Mchugh \& Manuel Bessler, Humanitarian Negotiations with Armed Groups: A Manual For Practitioners, and Guidelines on Humanitarian Negotiations With Armed Groups, United Nations Office for the Coordination of Humanitarian Affairs (OCHA) in collaboration with members of the Inter-Agency Standing Committee (IASC), 2006, p. 1.

${ }^{45}$ William T. Worster, "Relative International Legal Personality of Non-State Actors", op. cit., p. 207, Available at: https:/ / brooklynworks.brooklaw.edu/bjil/ vol42/iss1/4

${ }^{46}$ Ibid., p. 208.

${ }^{47}$ Hans-Joachim Heintze, Do Non-State Actors Challenge International Humanitarian Law?, In: von Heinegg W.H., Epping V. (eds) International Humanitarian Law Facing New Challenges. Springer, Berlin, Heidelberg, 2007, p. 163

${ }^{48}$ Ibid. 
Nedemokratskim i drugim kriminalnim organizacijama, koje koriste nasilje za postizanje svojih ciljeva, ne može se priznati status legalnih aktera u međunarodnom pravu. ${ }^{49}$

Ima autora koji nedržavne aktere definišu i kao bilo koju oružanu grupu koja je odvojena od države i ne funkcioiše pod kontrolom države ili država u kojoj preduzimaju vojne operacije i koje imaju političke, religijske i/ili vojne ciljeve..$^{50}$

Kada je reč o nedržavnim akterima koji učestvuju u oružanim sukobima najčešće se pominju oni narodi koji su istakli svoje pravo na samoopredeljenje i pokreti za nacionalno oslobođenje. Obe kategorija lica uživaju svoja prava na teritoriji na kojoj žive. ${ }^{51}$

U doktrini međunarodnog humanitarnog prava razlikuju se pojmovi nedržavni akteri i nedržavni entiteti. Razlika je izvedena na osnovu stepena organizovanosti. Stepen organizacije je važan faktor $u$ priznavanju određenih pobunjeničkih grupa za stranu $u$ sukobu. Priznanje pobunjenika za stranu u sukobu povlači specifičan položaj u međunarodnom pravu, zatim prava i obaveze kako za pobunjenike tako i za oružane snage države.

Po Šindleru (D. Schindler), izraz nedržavni entiteti obuhvata ,,svaku grupu ili frakciju koja učestvuje u neprijateljstvima protiv vlade ili nekog drugog sličnog entiteta“ ${ }^{52}$ Pod kvazidržavnim entitetima smatraju se pobunjenici, vlade u egzilu koje nastavljaju oružanu borbu, narodno-

${ }^{49}$ Ibid.

${ }^{50}$ Annyssa Bellal, Gilles Giacca, and Stuart Casey-Maslen, "International law and armed non-state actors in Afghanistan", International Review of the Red Cross, Volume 93 Number 881 March 2011. p. 47.

${ }^{51}$ William T. Worster, "Relative International Legal Personality of Non-State Actors", op. cit., p. 208.

${ }^{52}$ Dietrich Schindler, "The Different Types of Armed Conflicts According to the Geneva Conventions and Protocols (Volume )", in: Collected Courses of the Hague Academy of International Law, 1979, Vol. 163, p. 125,

The Yearbook of the Institute of International Law (Yearbook), 1999, Centenary Session, Roma, 1973, Vol. 55, pp.515-516; Cf., The Yearbook of the Institute of International Law, 68-I, 1999, pp. 263, 329. 
oslobodilački pokreti, zaraćene strane koje su kao takve priznate, kao i razne grupe ili kolektiviteti koji su se podigli na oružje..$^{53}$

U toku rada Komisije za izradu Rezolucije o primeni međunarodnog humanitarnog prava i osnovih ljudskih prava u oružanim sukobima u kojima učestvuju nedržavni entiteti ( $u$ daljem tekstu Rezolucija o oružanim sukobima u kojima učestvuju nedržavni entiteti), bilo je dosta diskusije oko pojmova "nedržavni entiteti“ i „oružani sukob u kojima uzimaju učešće nedržavni entiteti“. Problemi su nastali pre svega oko toga da izraz "nedržavni entiteti“ nije pravni termin i da $u$ međunarodnom pravu nije jasno definisan, kao i izraz „oružani sukob u kojima uzimaju učešće nedržavni entiteti“" ${ }^{54}$ uzimajući u obzir da su oružani sukobi u kojima su nedržavni entiteti strane sve brojniji i sve motivisaniji naročito etničkim, verskim ili rasnim uzrocima. ${ }^{55}$

Ovde posebno treba istaći da su promene u oružanim sukobima u drugoj deceniji XXI veka uticale i na proširivanje definicije nedržavnih aktera. Veći stepen organizovanosti kod nekih grupa, koje inače ne bi bile obuhvaćene definicijom, primorale su doktrinu ali i međunarodna tela da ih uključe pod nedržavne aktere. Poseban razlog leži u činjenici da su upravo ovi akteri izvršili teška kršenja međunarodnog prava oružanih sukoba.

Oružani sukobi u kojima učestvuju nedržavni entiteti ne pogađa samo države na čijoj teritoriji se odvijaju, već utiče i na čitavu međunarodnu zajednicu. ${ }^{56}$

Uzimajući u obzir presude Međunarodnog krivičnog tribunala za bivšu Jugoslaviju, po kojima su mnoga načela i pravila koja su se ranije

${ }^{53}$ Dietrich Schindler, "The Different Types of Armed Conflicts According to the Geneva Conventions and Protocols (Volume)", op. cit., p. 126.

${ }^{54}$ Vladan Jončić, "Značaj Berlinske rezolucije o primeni međunarodnog humanitarnog prava u oružanim sukobima u kojima učestvuju nedržavni entiteti“", op. cit., str. 175-196.

55 "The Application of International Humanitarian Law and Fundamental Human Rights", in Armed Conflicts in which Non-State Entities are Parties, The Institute of International Law, Session of Berlin, 1999.

56 Ibid. 
primenjivala samo $\mathrm{u}$ međunarodnim oružanim sukobima sada primenljiva $u$ unutrašnjim oružanim sukobima, a ozbiljna kršenja međunarodnog humanitarnog prava počinjena $\mathrm{u}$ kontekstu poslednje kategorije sukoba, predstavljaju ratni zločin. ${ }^{57}$

Pojava novih aktera, korporativnih agenata, $\mathrm{u}$ oružanim sukobima uticala je i na određivanje kategorije nedržavnih aktera. Ovi novi učesnici $\mathrm{u}$ oružanom sukobu nisu dobili precizno utvrđen status. ${ }^{58}$ Bilo bi pogrešno ove učesnike bezrezervno smatrati nedržavnim akterima, koji u međunarodnom humanitarnom pravu raspolažu određenim pravima i obavezama. Ovo bi bio pogrešan korak jer oni nemaju jasno utvrđen status legalnog učesnika u oružanim sukobu. „Korporativni agenti“ su lica koja su angažovana od strane privatnih vojnih kompanija da $u$ interesu privatne vojne kompanije i država koje ih angažuju, ali za svoj račun (zarada), učestvuju na različite načine u oružanim sukobima ili sličnim vanrednim okolnostima. ${ }^{59}$

Status ovih aktera u oružanom sukobu predstavlja temeljni problem za njihovno svrstavanje $u$ nedržavne aktere koji uzimaju učešće $u$ oružanom sukobu. $\mathrm{Na}$ osnovu postojećih normi, mišljenja doktrine i faktičkog stanja ne može se jasno utvrditi da li su oni legalni borci, plaćenici, neborci ili pak civili. Korporativni agenti imaju neke elemente novog vida plaćenika. ${ }^{60}$ Prilikom određivanja njihovog statusa mora se poći od pitanja njihovih motiva za učestvovanje u oružanom sukbu, koji je čisto lukrativan, pa je teško isključiti ih iz definicije plaćenika. Kao i ostali učesnici u oružanom sukobu i korporativni agenti mogu da menjaju status, pa u jednom trenutku da budu civili, odnosno korporativni agenti (lica sa neutvrđenim pravnim statusom), kasnije da uzmu učešće u borbama, kako bi se nakon tog angažovanja ponovo vratili u položaj civila.

Norme savremenog humanitarnog prava ne definišu položaj i status korporativnih agenata. U instrumentima međunarodnog prava oružanih

\footnotetext{
57 Ibid.

${ }^{58}$ Miloš Jončić, Međunarodnopravni položaj civilnog stanovništva u oružanim sukobima, Institut za međunarodnu politiku i privredu, Beograd, 2019, str. 91.

${ }^{59}$ Miloš Jončić, „Savremene tendencije u razvoju međunarodnog humanitarnog prava“", op. cit., str. 179.

${ }^{60}$ Ibid.
} 
sukoba ništa ne upućuje da su „korporativni agenti“ prihvaćeni kao legalni učesnici u oružanim sukobima, čak naprotiv tumačenjem normi i dokumenata pre se mogu svrstati u grupu savremenih oblika plaćeništva. Doktrina stoji na nešto drugačijem stanovištu. Postoji tedencija da se ova grupa nedržavnih aktera svrsta u legalne učesnike kako bi dobili zaštitu. Autori koji zastupaju ovu tezu navode da su pripadnici privatnih vojnih kompanija uglavnom lica čiji se zadatak svodi na davanje saveta ili pomoći u obuci oružanih snaga. Na osnovu ovih zadataka neki autori, među kojima i Ketrin Falah (Katherine Fallah), ističu da lica angažovana od strane privatnih vojnih kompanija treba da imaju status drugačiji od stausa klasičnih plaćenika. ${ }^{61}$

Suprotno mišljenje imaju autori koji potpuno suprotno tumače norme, doktrinu i praksu i upućuju da se ovim akterima nikako ne sme priznati status legalnih učesnika $u$ oružanom sukobu. Oni ukazuju da međunarodnopravna pravila daju pre osnova za zaključak da su korporativni učesnici (Corporate actors) u suštini plaćenici, ili u najboljem slučaju civili. ${ }^{62} \mathrm{U}$ doktrini postoje i tvrdnje da svi udruženi učesnici (Corporate actors) ne spadaju pod definiciju najamnika po međunarodnom pravu. ${ }^{63}$ Norme tzv. „Plaćeničkih konvencija“ i Protokola I upućuje na zaključak, to prihvata i većina teoretičara, da ova lica nemaju osnova da dobiju status boraca i da eventualno mogu dobiti samo minimalnu zaštitu koju pruža međunarodno humanitarno pravo, po nekom drugom statusu. ${ }^{64}$

Negativan stav o legalnosti korporativnih agenata potvrđen je $\mathrm{u}$ mnogim izveštajima. ${ }^{65}$ Interesantni su izveštaji koji ukazuju da su neretko

${ }^{61}$ Katherine Fallah, "Corporate actors: the legal status of mercenaries in armed conflicts", International Review of the Red Cross, ICRC, Geneve, 2005. Dostupno na: https://www.icrc.org/eng/assets/files/other/irrc_863_fallah.pdf

${ }^{62}$ Vladan Jončić, „Međunarodnopravni status pripadnika privatnih vojnih kompanija", op. cit., str. 306, str. 285-308.

${ }^{63}$ Ibid.

${ }^{64}$ Ibid.

${ }^{65}$ Slučaj „Faludža, (“Bodies mutilated in Fallujah attack”, BBS News (UK), 31 March 2004, available at http:/news.bbc.co.uk/2/hi/middle_east/3585765.stm> (posećeno 18.6.2020) 
pripadnici oružanih snaga nekih država, napuštali regularne snage ili pak uzimali odsustva u cilju priključivanja privatnim vojnim kompanijama. ${ }^{66}$

Osnovni cilj angažovanja korporativnih agenata u oružanom sukobu jeste prikrivanje odgovornosti država, koje ih angažuju, za uplitanje $u$ unutrašnje stvari drugih država. Na ovaj način odgovornost za akte koji nisu u skladu sa međunarodnim pravom prelaze na aktere kojima je teško utvrditi status, pa samim tim i način sankcionisanja za nepoštovanje pravila međunarodnog prava. Jedino preostaje individualna odgovornost za kršenje pravila međunarodnog humanitarnog prava. Formiranje oružanih snaga ostaje $u$ isključivoj nadležnosti država, a ipak po međunarodnom pravu postoji obaveza država da obaveste suprotnu stranu ukoliko u svoje oružane snage uključe miliciju i doborovaljačke jedinice (ili paravojne formacije). Norme koje regulišu pitanje drugih oblika oružanih snaga ni na jednom mestu ne definiše formacije sastavljene od korporativnih agenata.

\section{PRIMENA PRAVILA MEĐUNARODNOG PRAVA ORUŽANIH SUKOBA NA NEDRŽAVNE AKTERE}

Dok položaj i razvoj pravnog statusa nedržavnih aktera u opštem međunarodnom pravu može biti pozitivan, pojava nedržavnih aktera u vezi sa oružanim sukobima izaziva zabrinutost. ${ }^{67}$ Jer, međunarodno pravo se tada suočava sa pojavom oružanih opozicionih grupa koje se bore ili protiv zvaničnih administracija, odnosno vlada država, i/ili jedni protiv drugih. ${ }^{6}$ Iako se pravni status takvih grupa vrlo često smatra sumnjivim, sa stanovišta međunarodnog prava sukobi u koje su oni uključeni imaju nemeđunarodnu prirodu. ${ }^{69}$ Ovakav stav je opravdan

${ }^{66}$ Miloš Jončić, „Savremene tendencije u razvoju međunarodnog humanitarnog prava“, op. cit., str. 271; http:/news.indepedent.co.uk/world/middle_est/story. jsp?story $=505826$.

${ }^{67}$ Jakob Kellenberger, International Humanitarian Law at the Beginning of the 21st Century, Address to 26th Roundtable on Current Problems of International Humanitarian Law, San Remo, 5 September 2002. https://www.icrc.org/ en/doc/resources/documents/statement/5e2c8v.htm

${ }^{68}$ Hans-Joachim Heintze, op.cit., 2007. p. 164.

${ }^{69}$ Ibid. 
ukoliko govorimo o klasičnom obliku oružanog sukoba unutrašnjeg (nemeđunarodnog) karaktera u kome su sukobljene strane isključivo pobunjenici i oružane snage države ili pobunjenici međusobno. Ukoliko se na jednoj od sukobljenih strana pojavi strani faktor, reč je o internacionalizovanim ili pak mešovitim oružanim sukobima.

Posebno do izražaja dolazi stav doktrine da je neophodno utvrditi koja prava, dužnosti i obaveze imaju nedržavni akteri na međunarodnom planu. $^{70}$

Doktrina smatra da pobunjenici u oružanim sukobima direktno crpe prava i obaveze iz međunarodnog prava. ${ }^{71}$ Ovde treba precizirati da ne uživaju svi pobunjenici status da crpe direktno prava iz međunarodnih normi. Neophodno je ispunjenje nekoliko uslova. Prvo moraju postići priznanje kao strane $u$ oružanom sukobu, a time im se otvara mogućnost da se jednostranom izjavom obavežu na poštovanje pravila međunarodnog humanitarnog prava.

Jednostrana izjava volje je jedan od načina na koji nedržavni akteri u međunarodnom pravu mogu da iskažu svoju spremnost, ali i obavezu da poštuju pravila međunarodnog humanitarnog prava. Jedan od primera je Izjava na konferenciji u Ženevi 24. janura 1995, koju je dala Radnička partija Kurdistana (The Kurdistan Workers Party), a na kojoj je saopštila da će njihove snage u sukobu sa turskim državnim snagama poštovati Ženevske konvencije iz 1949. i Protokol I iz 1977. o vođenju neprijateljstava i zaštiti žrtva rata, i da te obaveze imaju obavezujuću snagu u okviru njihovih oružanih snaga, kao i na teritoriji koju kontrolišu. ${ }^{72}$

Minimum zaštite, ali i obavezu poštovanja za nedržavne aktere $u$ oružanom sukobu obezbeđuje član 3 Ženevskih konvencija, ${ }^{73}$ koji se primenjuje ne samo $u$ situacijama $u$ kojima su kao strane $u$ sukobu $u$

${ }^{70}$ William T. Worster, „Relative International Legal Personality of Non-State Actors", op. cit., p. 208.

${ }^{71}$ Ibid., p. 230.

72 PKK Statement To The United Nations, Geneva, 24 January, 1995, dostupno na: http:/ / www.hartford-hwp.com/archives/51/009.html

${ }^{73}$ Ženevske konvencije o zaštiti žrtava rata od 1949. godine, Izvori međunarodnog humanitarnog prava, Jugoslovenski crveni krst, Beograd, 1999. 
smislu zajedničkog člana 3 uključene na jednoj strani vladine oružane snage, a na drugoj pobunjenici, već i u slučajevima u kojima se nevladine oružane grupe bore jedna protiv druge. ${ }^{74}$

Ovi entiteti imaju određeni stepen efektivne kontrole teritorije $u$ vojnom smislu, veoma su dobro organizovani, čak mogu uspostaviti i interni pravni poredak $u$ toj meri da liče na organizovane države. Druge države često ulaze u saradnju sa ovim entitetima, ali oni ipak ne mogu steći sva prava koja proizilaze iz nezavisnosti i suvereniteta.

Institut za međunarodno pravo je na svom zasedanju u Milanu 1993. godine doneo odluku da se pristupi izradi studije koja bi analizirala sprovođenje međunarodnog prava $u$ toku oružanih sukoba $u$ koje su uključeni nedržavni entiteti i uloge humanitarnog prava u njima. $U$ toku rada Komisije, koja je tada formirana da izradi studiju, iskristalisala su se pitanja koja su tražila odgovore $u$ vezi sa sprovođenjem međunarodnog humanitarnog prava $u$ takvim sukobima. Institut je konačno usvojio nacrt Rezolucija o oružanim sukobima u kojima učestvuju nedržavni akteri na svom sastanku u Berlinu 25. avgusta 1999. godine. ${ }^{75}$ Nekoliko činjenica je utvrđeno tokom izrade ove studije. Najpre da su oružani sukobi u kojima učestvuju nedržavni entiteti sve brojniji, zatim da je u tim sukobima porasla ugroženost civilnog stanovništva, da ovi sukobi nisu samo unutrašnja stvar države već da postoji zainteresovanost čitave međunarodne zajednice, da je uključeno i mišljenje pravosudnih tela pre svega Međunarodnog krivičnog tribunala za bivšu Jugoslaviju. ${ }^{76}$ Član 5e obavezuje države i nedržavne entitete koji učestvuju u nekom oružanom sukobu da poštuju međunarodno humanitarno pravo u svim prilikama, bez obzira da li države i nedržavni entiteti osporavaju postojanje oružanog sukoba. Istovremeno, pruženo je pravo svakoj državi, bez obzira što ne učestvuje u tom oružanom

\footnotetext{
${ }^{74}$ William T. Worster, ,"Relative International Legal Personality of Non-State Actors", op. cit., p. 208.

${ }^{75}$ Vladan, Jončić, ,ZZnačaj Berlinske rezolucije o primeni međunarodnog humanitarnog prava u oružanim sukobima u kojima učestvuju nedržavni entiteti“ ${ }^{\prime \prime}$ op. cit., 566, str. 175-196.

${ }^{76}$ Ibid.
} 
sukobu, da zahteva poštovanje ovog prava što predstavlja prihvatanje klauzule erga omnes. ${ }^{77}$

Neki autori smatraju da samo države mogu biti odgovorne za kršenje pravila o zaštiti ljudskih prava, dok sa druge strane i države i oružane grupe (čitaj nedržavni akteri) mogu biti odgovorni za kršenje pravila međunarodnog humanitarnog prava. ${ }^{78}$ Zato, ovi autori smatraju da nedržavni akteri ne mogu formalno „kršiti“ ljudska prava, već mogu samo zloupotrebiti pravila o ljudskim pravima. Ovakvo shvatanje je logično iz činjenice da su ljudska prava na snazi u doba mira, dok humanitarno pravo predstavlja poseban korpus prava koji stupa na snagu momentom nastanka oružanog sukoba. Nisu retki slučajevi u kojima su pobunjenici opravdavali svoje akte time da je njihovo delovanje usmereno na sprečavanje daljeg kršenja njihovih ljudskih i manjinskih prava. ${ }^{79}$

Ujedinjene nacije raspolažu nizom sporazuma između država i nedržavnih oružanih grupa.

Da bi se ispoštovala pravila međunarodnog humanitarnog prava sukobljene strane često zaključuju sporazume u kojima se obavezuju na poštovanje pravila međunarodnog humanitarnog prava. U ovim sporazumima se pored opšteg prihvatanja normi često navodi šta će strane preduzeti kako bi ispunili obaveze iz sporazuma.

Tako u „Ugovoru o komponenti civilne zaštite Međunarodnog posmatračkog tima“, Vlada Republike Filipini i Moro Islamski Oslobodilački Front (Moro Islamic Liberation Front) su prihvatili: „Strane su saglasne da poštuju međunarodno humanitarno pravo i ljudska prava kako bi obezbedili konstantnu zaštitu za civilno stanovništono i civilne objekte u toku

77 The Application of International Humanitarian Law and Fundamental Human Rights, in Armed Conflicts in which Non-State Entities are Parties, The Institute of International Law, Session of Berlin, 1999.

${ }^{78}$ Ibid., p. 231.

${ }^{79}$ Čitava pobuna Oslobodilačke vojske Kosova (OVK) i svi teroristički akti su pravdani njihovim zalaganjem da Savezna Republika Jugoslavija prestane sa ugnjetavanjem, kršenjem ljudskih prava, nepoštovanjem manjinskih prava. Vremenom je zaključeno da ovo ipak nisu bili centralni i konačni ciljevi OVK, već su to u prvoj fazi formiranje tzv. nezavisne države Kosovo, koja bi kasnije ušla u sastav Velike Albanije. Sličan slučaj je i sa Opozicionim grupama u Siriji. 
oružanog sukoba" ${ }^{80} \mathrm{U}$ nastavku strane su potpisale i obavezu: „Da bi postigli gore navedene ciljeve, Strane će izdati ili ponovo izdati naredbe svojim vojnim jedinicama ili bezbednosnim snagama (uključujući paravojne jedinice, pridružene milicije i policijske jedinice) da sprovode svoje operacije u skladu sa svojim obavezama i obavezama opisanim u ovom dokumentu“ ${ }^{81}$

Posebno pitanje jeste poštovanje običajnog međunarodnog humanitarnog prava $\mathrm{i}$ da li praksa nedržavnih aktera doprinosi međunarodnom običajnom pravu. Postoje mišljenja naučnika, ali i sudova da praksa i aktivnosti nekih nedržavnih aktera ukazuju da oni teže prihvatanju pravila običajnog međunarodnog prava.

Međunarodni krivični sud za bivšu Jugoslaviju uzeo je u obzir aktivnosti nedržavnih aktera u oceni običajnog međunarodnog prava, ali samo u ograničenom kapacitetu. ${ }^{82}$

Prema članu 7 Rimskog statuta Međunarodnog krivičnog suda, zločine protiv čovečnosti mogu počiniti osobe koje deluju ili za državu ili za nedržavne entitete. ${ }^{83}$

$\mathrm{Na}$ ovaj način je Rimski statut priznao nedržavne entitete kao učesnike $u$ oružanom sukobu koji moraju da poštuju pravila međunarodnog humanitarnog prava, posebno ona koja se odnose na zločin protiv čovečnosti.

${ }^{80}$ Agreement on the Civilian Protection Component of the International Monitoring Team (IMT), United Nations, 27/10/2009 Article 1, dstupno na: https://peace maker.un.org/sites/peacemaker.un.org/files/PH_091027_Agreement\%20on\%20 Civilian\%20Protection \%20Component.pdf

${ }^{81}$ Ibid.

${ }^{82}$ William T. Worster, "Relative International Legal Personality of Non-State Actors", op. cit., p. 237.

83 The Application of International Humanitarian Law and Fundamental Human Rights, in Armed Conflicts in which Non-State Entities are Parties, The Institute of International Law, Session of Berlin, 1999. 


\section{PRAKTIČNA PRIMENA PRAVILA MEĐUNARODNOG PRAVA NA NEDRŽAVNE AKTERE (PROBLEMI I REŠENJA)}

Ako se napravi osvrt na gore navedenu definiciju nedržavnih oružanih grupa iz „Uputstva za humanitarne pregovore sa oružanim grupama“ može se videti da se humanost stavlja ispred određenih pravila. Iz ove definicije vidi se da je za praktičnu primenu humanitarnog prava prihvatljiva i šira definicija koja obuhvata i neke nedržavne aktere koji se ne mogu smatrati u potpunosti legalnim učesnicima. Ova definicija je data za potrebe Uputstva za pregovore sa oružanim grupama. Zbog potreba humanosti dozvoljeno je pregovarati i sa nepriznatim akterima kako bi se ispunila svrha, a to je zaštita ugroženih kategorija lica u oružanim sukobima.

Ujedinjene nacije su u više navrata reagovale i upozoravale na teška kršenja međunarodnog prava u sukobima u kojima učestvuju nedržavni akteri. U sukobu u Iraku došlo je do niza povreda međunarodnog prava od strane nedržavnih aktera. U rezoluciji, donetoj na 22. zasedanju Saveta za ljudska prava, utvrđeno je da su tzv. Islamska država u Iraku i Levantu i pridružene terorističke grupe izvršile akte koji se mogu podvesti pod zločine protiv čovečnosti, uključujući nezakonita ubijanja, seksualno nasilje nad ženama i decom, porobljavanje, silovanja, prisilne brakove, raseljavanje i otmice. ${ }^{84}$ Ovi akti nedržavnih aktera izazvali su katastrofalnu humanitarnu krizu i raseljavanje velikog broja ljudi iz područja koja su pod kontrolom ovih aktera.

Na sastanku u Abudži (Abuja), u Nigeriji, održan je susret pod pokroviteljstvom Afričke unije na kom su vlada Sudana, s jedne strane, i Oslobodilački pokret / vojska Sudana (Sudan Liberation Movement/Army) i Pokret pravde i ravnopravnosti (The Justice and Equality Movement), s druge strane, zaključili sporazum u cilju pronalaženja trajnog rešenja

\footnotetext{
${ }^{84}$ Resolution adopted by the Human Rights Council, The human rights situation in Iraq in the light of abuses committed by the so-called Islamic State in Iraq and the Levant and associated groups, Human Rights Council, Twenty-second special session, A/HRCC/RES/S-22/1, 3 September 2014.
} 
sukoba u Darfuru. ${ }^{85}$ Tom prilikom su istakli svoju zabrinutost za humanitarnu krizu u Darfuru i posledice te krize na civilnu populaciju, posebno na žene i decu, kao i raširenost ljudske patnje koju pritom trpe lica zahvaćena tim sukobom. ${ }^{86}$ Sve strane uključene u sukob obavezale su se na poštovanje humanitarnih principa iz Povelje Ujedinjenih nacija kao i iz drugih relevantnih instrumenata. Posebno su naveli poštovanje principa neutralnosti i nepristrasnosti, humanitarne pomoći i samih humanitarnih i medicinskih radnika. ${ }^{87}$ Saglasnost se odnosila i na niz mera koje strane treba da preduzmu kako bi zaštitili civilno stanovništvno, a kao osnovna obaveza navedeno je da strane treba da preduzmu sve potrebne mere kako bi sprečili sve napade, pretnje, zastrašivanja i sve druge oblike nasilja protiv civila od strane bilo koje od strana ili grupa ${ }^{88}$ Ova obaveza se naslanja na pravila o zaštiti civilnog stanovništva počevši od Ženevske konvencije o zaštiti civilnog stanovništva u oružanim sukobima (IV Ženevska konvencija). ${ }^{89}$

Da bi obezbedile poštovanje i zaštitu civilnog stanovništva i civilnih objekata, strane u sukobu treba u svako doba da prave razliku između civilnog stanovništva i boraca, i između civilnih objekata i vojnih objekata i da, shodno tome, usmere sve vojne operacije samo protiv vojnih objekata. ${ }^{90}$ Civilno stanovništvo i pojedini civili uživaju opštu zaštitu od opasnosti koje proističu iz vojnih operacija. Da bi se sprovela ta zaštita poštovaće se, u svakoj prilici, sledeća dodatna pravila, pored drugih primenjivih pravila međunarodnog prava. ${ }^{11}$ Civilno stanovništvo

${ }^{85}$ Protocol Between the Government of the Sudan, Sudan Liberation Movement/ Army and the Justice and Equality Movement on the Improvement of the Humanitarian Situation in Darfur, Nov. 9, 2004.

${ }^{86}$ Ibid.

${ }^{87}$ Ibid.

88 Ibid.

${ }^{89}$ Ženevska konvencija o zaštiti Građanskih lica za vreme rata od 12. avgusta 1949. (IV Ženevska konvencija), Izvori međunarodnog humanitarnog prava, Jugoslovenski crveni krst, Beograd, 1999.

${ }^{90}$ Dopunski protokol uz Ženevske konvencije od 12. avgusta 1949. godine o zaštiti žrtava međunarodnih oružanih sukoba (Protokol I), Izvori među-narodnog humanitarnog prava, Jugoslovenski crveni krst, Beograd, 1999, Čl. 48 Protokola I.

${ }^{91} \check{C}$ l 51 st. 1 Protokola I. 
kao takvo, kao i pojedini civili, neće biti predmet napada. Zabranjeni su akti ili pretnje nasiljem, kojima je glavni cilj da šire teror među civilnim stanovništvom. ${ }^{92}$ Civili će uživati zaštitu ukoliko ne uzimaju direktnog učešća u neprijateljstvima, odnosno za vreme dok ne uzimaju direktnog učešća u neprijateljstvima. ${ }^{93}$

Duboko zabrinuti sve većim i dramatičnim kršenjima ljudskih prava i zloupotrebama, i kršenjima međunarodnog humanitarnog prava u Iraku proizašlim iz terorističkih akata koje je počinila takozvana Islamska država u Iraku i Levantu i pridružene terorističke grupe protiv iračkog naroda, posebno onim kršenjima koje uključuju nezakonito ubijanje, namerno gađanje civila, ciljani progon pojedinaca na osnovu njihove religije ili verovanja, i nasilna dela nad pripadnicima etničkih i verskih manjina, posebno hrišćana i Iazidisa u Mosulu i okolini, uključujući Sinjar (Sinjar), Tal Afar (Tal Afar), Bašir (Bashir), Amerli (Amerli), Ninevska nizina i druga područja, kao i opsade civila u selima u kojima žive manjine. ${ }^{94}$

Primena zajedničkog člana 3 Ženevskih konvencija o zaštiti žrtava rata nije sporna, dok je na pitanje kako i na šta se proširuje primena Protokola II teže odgovoriti, posebno u odnosu na različite oružane aktere koji deluju $\mathrm{u}$ zemlji u kojoj postoji sukob. Posebno je problematično pitanje primenjivosti međunarodnog prava ljudskih prava od strane oružanih nedržavnih aktera. Ovo pitanje je posebno problematično u sukobima u Avganistanu. Ipak, primenljivost ljudskih prava na takve aktere koji vrše kontrolu nad stanovništvom polako postaje sve prihvaćenija. Pored toga, kršenja peremptornih normi međunarodnog prava mogu direktno uključiti pravnu odgovornost takvih grupa. ${ }^{95}$ Kada je reč o snazi i strukturi

${ }_{92}^{92}$ Ibid., Čl. 51 st. 2.

${ }^{93}$ Ibid., Čl. 51 st. 3.

${ }^{94}$ Resolution adopted by the Human Rights Council, The human rights situation in Iraq in the light of abuses committed by the so-called Islamic State in Iraq and the Levant and associated groups, Human Rights Council, Twenty-second special session, A/HRCC/RES/S-22/1, 3 September 2014.

${ }^{95}$ Annyssa Bellal, Gilles Giacca, and Stuart Casey-Maslen, "International law and armed non-state actors in Afghanistan", International Review of the Red Cross, Volume 93 Number 881 March 2011. p. 47. 
naoružanih nedržavnih aktera u Avganistanu nema konsenzusa među stručnjacima. ${ }^{96}$

Najčešće pominjana grupa nedržavnih aktera su Talibani. Talibani su se pojavili početkom devedesetih u severnom Pakistanu usred nasilja koje je usledilo nakon povlačenja sovjetskih trupa iz Avganistana. ${ }^{97}$ Svoj snažan uticaj i brojnost su iskazali vrlo brzo s obzirom na to da su od početne zastupljenosti u jugozapadnom Avganistanu vrlo brzo proširili svoju kontrolu nad celom zemljom. Krajem 1996. godine, preciznije u septembru, zauzeli su glavni grad Kabul, a do 1998. su kontrolisali $90 \%$ teritorije države. Do dolaska koalicije, koju predvode SAD, 2001. godine Talibane su kao legitimnu vladu priznali Pakistan, Saudijska Arabija i Ujedinjeni Arapski Emirati. ${ }^{98}$ Rat u Avganistanu završio se porazom talibanske vlasti. Nakon tog poraza izbila je pobuna protiv vlade koje je izabrana 2002. godine. Pobuna je svake godine povećavala svoj intezitet. Misija za pomoć UN u Avganistanu (United Nations Assistance Mission in Afghanistan) za nedržavne aktere uključene u pobunu koristi izraz "anti-vladini elementi“, koji obuhvata pojedince i oružane grupe različitog porekla, motivacije i komandne strukture. Tu su uključeni i Talibani, Hakani mreža, ${ }^{99}$ Hezb-e-Islami (Hezb-i-Islami Afghanistan) i drugi.

Civilno stanovništvno je platilo visoku cenu tokom sukoba $\mathrm{u}$ Avganistanu. Osnovni razlog patnji civilnog stanovništva jesu naoružane nedržavne grupe. Talibani i srodne pobunjeničke grupe u Avganistanu pokazuju veoma malo poštovanja za ljudska prava, pravila međunarodnog prava oružanih sukoba i namerno gađaju civile,

${ }^{96}$ Ibid.

${ }^{97}$ James Fergusson, Taliban: The True Story of the World's Most Feared Fighting Force, Bantam Press, London, 2010, p. 15.

${ }^{98}$ International Crisis Group, 'Taliban propaganda: winning the war of words?', Dostupno na: https://www.crisisgroup.org/asia/south-asia/afghanistan/ taliban-propaganda-winning-war-words

${ }^{99}$ Mreža Hakkani (Haqqani network) je avganistanska gerilska pobunjenička grupa koja koristi asimetrični rat za borbu protiv NATO snaga koje predvode SAD i vlada Avganistana. 
zdravstvene radnike i civilne objekte među kojima su najčešća meta napada škole, posebno škole za devojčice. ${ }^{100}$

Veoma je važno da se obezbedi poštovanje ne samo međunarodnog humanitarnog prava, već i međunarodnog prava o ljudskim pravima u nastojanju da se postigne suštinsko poštovanje međunarodnih normi od strane naoružanih nedržavnih aktera u Avganistanu. Najbolje rešnje bi bilo formiranje posebnog sistema nadzora kontrolisanog od strane UN, a podržanog od strane nevladinih organizacija koje se bave ljudskim pravima i međunarodnim humanitarnim pravom. Organizacije za ljudska prava treba uključiti iz razloga što je i nakon okončanja neprijateljstava, ali i dok traje zamrznuti konflikt, ${ }^{101}$ neophodno nastaviti nadzor, posebno ako je nakon sukoba došlo do pokušaja formiranja odvojene teritorije ili države koja još nije stekla svoj puni suverenitet, već se nalazi u pravnom vakuumu. Pravni vakuum podrazumeva formiranje nekog oblika vlasti, ali bez potpunog formiranja državnog sistema.

Stanje ljudskih prava i primene međunarodnog humanitarnog prava u Sirijskoj Arapskoj Republici se, po nekim izvorima, pogoršavalo od početka sukoba. Od 15. jula 2012. godine došlo je do eskalacije oružanog sukoba između vladinih snaga i antivladinih oružanih grupa. Sukob je postajao sve radikalniji i militantniji. ${ }^{102}$

Evolucija krize u Siriji, prema izveštajima UN istražne komisije, navodi da se istraži u kojim situacijama unutrašnje tenzije i poremećaji prelaze u ne-međunarodni oružani sukob. ${ }^{103}$

${ }^{100}$ Amnesty International, 'Afghanistan conference raises fears of sacrificing rights for short-term peace', 19 July 2010, dostupno na: https:/ / www.amnesty.org/ en/ latest/news/2010/07/temor-conferencia-afganistan-sacrifique-derechos-por-paz/

${ }^{101}$ Više o zamrznutim konfliktima u Vladimir Trapara, Miloš Jončić: „Put za rešavanje sukoba - uporedna analiza zamrznutih sukoba na prostoru OEBS", Međunarodni problemi, Institut za međunarodnu politiku i privredu, godina LXIV br. 2, 2012, str. 275-302.

${ }^{102}$ Report of the independent international commission of inquiry on the Syrian Arab Republic, Human Rights Council, Twenty-second session, United Nations, General Assembly, A/HRC/22/59.

103 Tilman Rodenhäuser, "International legal obligations of armed opposition groups in Syria", Jurnal of International Review of Law, Qatar University, Vol . 2015 No. 1, 2015, p. 10. 
Sukob u Siriji zahteva mnogo pažnje kada je reč o sukobljenim stranama. Sa jedne strane su vladine oružane snage u koje su uključeni i pripadnici milicije, koji koriste strategiju "stezanja“ u borbi sa narastajućom pobunom. Vladine snage su se koncentrisale da zadrže velike gradove, ali su se trudile da u manjim gradovima, koji su pod opsadom ili u rukama pobunjenika, obnove oružane snage i različite slojeve snaga bezbednosti. ${ }^{104}$

Na strani oružanih snaga koje podržavaju legalno izabrani režim su i oružane grupe za samoodbranu formirane od provladinih zajednica poznatih i kao „Narodni odbori“. Narodni obori su nastavili da štite svoje četvrti i lokacije od antivladinih oružanih grupa i da učestvuju u vojnim operacijama zajedno sa vladinim snagama. Navodno su ih naoružali i opremili vlada, a u nekim oblastima i spoljni simpatizeri. ${ }^{105}$ Gradovi pod kontrolom nedržavnih oružanih grupa pretrpeli su pojačano artiljerijsko i vazdušno granatiranje. Ostale, uglavnom ruralne oblasti, vlasti su potpuno napustile, ali su one i dalje bile granatirane od strane pobunjenika. Pored konvencionalne municije, korišćene su i druge vrste municije, uključujući kasetne vazdušne bombe i artiljerijske granate. Nijedna strana nije dokumentovala verodostojne dokaze o upotrebi hemijskog oružja. Pretpostavka je da nijedna strana nije koristila hemijsko oružije u klasičnom smislu. Postoji osnovana sumnja da su nedržavni oružani akteri odlagali i skladištili hemijske supstance na lokacije za koje su znali da će biti predmet napada ili granatiranja. Sigurnost da će baš te lokacije biti predmet napada dolazila je iz činjenice da su sa tih lokacija napadali vladine oružane snage. Ovu perfidiju su koristili s ciljem da vladine oružane snage budu optužene, od strane međunarodne zajednice, za upotrebu hemijskog oružija.

Sa druge strane, situacija je daleko komplikovanija. Kada se govori o antivladinim oružanim grupama i pored velike podeljenosti među njima sama pobuna je nastavljala da raste u oružanu snagu koja je postajala

\footnotetext{
${ }^{104}$ Report of the independent international commission of inquiry on the Syrian Arab Republic, Human Rights Council, Twenty-second session, United Nations, General Assembly, A/HRC/22/59. p. 7. ${ }^{105}$ Ibid.
} 
sposobna da izazove sumnju u sposobnost vlade da zadrži kontrolu nad zemljom i da nastavi sa napadima na strateške ciljeve kao što su naftna polja i aerodromi. ${ }^{106}$

U severnim i centralnim provincijama, nedržavni akteri su prošili kontrolu nad teritorijom, dok su se u južnim i pomorskim oblastima nastavile borbe. ${ }^{107}$

Broj stranih boraca se vremenom povećavao, ali je sve vreme predstavljao manji deo antivladinih oružanih grupa. Njihova stručnost i iskustvo u ratu na strani pobunjenika bili su važni za taktičku efikasnost opozicije. Oni su došli iz zemalja Bliskog istoka, Severne Afrike i Centralne Azije, od kojih su mnogi iz Libije, Tunisa, Saudijske Arabije, Libana, Iraka i Egipta. ${ }^{108}$

Napadi na bolnice, medicinske jedinice i osoblje bile su sve intenzivnije i na taj način pogoršale ionako lošu socijalno-ekonomsku sliku. Zdravstveno osoblje je napuštalo svoje položaje, a u bolnicama je ponestajalo zaliha. Ovakva situacija je ograničavala pristup zdravstvenoj zaštiti, uključujući i onu predviđenu najugroženijim kategorijama, pre svega civilnom stanovništvu. ${ }^{109}$

Nedržavne oružane grupe podležu različitim međunarodnim pravnim pravilima, uključujući međunarodno humanitarno, međunarodno krivično i međunarodna pravila o ljudskim pravima. U svetlu razorne krize u Siriji, međunarodni pravnici su i razjasnili postojeća pravna pravila i izneli argumente koji dalje razvijaju međunarodno pravo. ${ }^{110}$

Lista kršenja pravila međunarodnog humanitarnog prava od strane nedržavnih aktera je prilično velika. Kako se na samom terenu situacija rešava u korist vladinih snaga možemo predvideti da će odgovorni za

\footnotetext{
106 Ibid.

107 Ibid.

${ }^{108}$ Ibid., p. 8.

${ }^{109}$ Ibid.

110 Tilman Rodenhäuser, “International legal obligations of armed opposition groups in Syria", op. cit., 2015, p. 15.
} 
najteža i najgrublja kršenja pravila međunarodnog humanitarnog prava biti izvedeni pred sudove i da će odgovarati za svoje postupke.

\section{ZAKLJUČAK}

Primena međunarodnog humanitarnog prava, ali i međunarodnih ljudskih prava, u sukobima i nakon okončanja sukoba u kojima učestvuju nedržavni akteri od velikog je značaja. Pre svega iz razloga što se broj oružanih sukoba u kojima učestvuju nedržavni akteri povećao nakon okončanja Hladnog rata. Prisustvo nedržavnih aktera u oružanim sukobima javilo se već sedamdesetih godina prošlog veka. Od tada počinje interesovanje za definisanja nedržavnih aktera u oružanim sukobima. Smatralo se da nedržavni akteri učestvuju samo u nemeđunarodnim (unutrašnjim) sukobima. Vremenom, posebno $u$ poslednje tri decenije, ova tvrdnja je opovrgnuta. Prisustvo nedržavnih aktera u oružanim sukobima se proširilo na gotovo sve oružane sukobe, uključujući tu i one oblike primene sile koji se nalaze negde između unutrašnjih i međunarodnih, a to su internacionalizovani i mešoviti.

Kolektivni entiteti, poput korporacija i NVO, kao i pojedinačni akteri (pojedinci), slično uživaju aspekte međunarodne pravne ličnosti na osnovu načina na koji funkcionišu u međunarodnom pravnom poretku. Neki od ovih entiteta, kao što su nacionalni oslobodilački pokreti, autohtoni narodi ili pobunjenici, imaju neku vrstu teritorijalnog postojanja, a njihova ličnost zamućuje se u državnost.

Definicije nedržavnih aktera obuhvataju niz lica ili grupa kojima treba dati priznanje i status legalnog učesnika u oružanom sukobu. Ipak, postoje i oni koji na osnovu niza činjenica ne smeju da dobiju status legalnog učesnika u oružanom sukobu. Ovde se pre svega misli na korporativne agente. Uvođenje korporativnih agenata $\mathrm{u}$ definiciju nedržavnih aktera koji uzimaju učešća u nekom od oblika primene sile jeste njihovo svrstavanje u legalne učesnike u oružanom sukbu i negacija niza normi međunarodnog prava oružanih sukoba koje ih drže izvan domašaja legalnosti.

$\mathrm{Na}$ zategnutosti i nemire na teritoriji države se ne primenjuje međunarodno humanitarno pravo. Da bi norme međunarodnog prava 
oružanih sukoba (humanitarnog prava) stupile na snagu neophodno je postojanje nekog od oblika oružanog sukoba, a za to je potreban jači intezitet oružanih akcija, obim angažovanja vojnih snaga, trajanje preduzetih akcija i teritorijalni opseg, odnosno raširenost tih akcija.

Sukobi na teritoriji bivše Jugoslavije su uključivali mnogo nedržavnih aktera i entiteta. Raznolikost tih aktera i nemogućnost kontrole svih oružanih grupa koje su učestvovale u oružanom sukobu doveli su do niza kršenja, ali i zloupotreba međunarodnog prava oružanih sukoba (međunarodnog humanitarnog prava). Sukob na teritoriji Autonomne Pokrajine Kosovo i Metohija posebno je obilovao zloupotrebama humanitarnog prava, ali i ozbiljnim kršenjima međunarodnog prava od strane pripadnika terorističke Oslobodilačke vojske Kosova. Posebno pitanje je da li se pripadnici Oslobodilačke Vojske Kosova mogu svrstati u grupu nedržavnih aktera?

Neki nedržavni akteri u pravnoj doktrini se smatraju licima koja uživaju prava, dužnosti, obaveze i predstavljaju međunarodnu pravnu ličnost, ali se oni smatraju grupama koje se razlikuju od država, i što se tiče subjektiviteta $u$ međunarodnim odnosima, ostaju bez subjektiviteta u međunarodnom pravu. Oni mogu dostići neki nivo kvazi ili krnjeg subjektiviteta, a njihova promenljiva pravna priroda im ne dozvoljava da steknu viši nivo subjektiviteta.

Nedržavni akteri, ne ulazeći u njihov pravni status nakon okončanja oružanog sukoba, mogu prihvatiti i obavezati se da će poštovati pravila međunarodnog humanitarnog prava. Kada ispune uslove koji su neophodni da bi bili priznati za stranu u sukobu, oružani nedržavni akteri mogu da daju jednostranu izjavu kojom se obavezuju da će poštovati norme međunarodnog humanitarnog prava, zatim mogu zaključiti sporazume sa državom sa čijim oružanim snagama su u sukobu, čime se obe strane obavezuju na poštovanje normi. Ono što ih obavezuje, bez obzira na to da li su i na koji način se obavezali na poštovanje pravila, jesu norme običajnog međunarodnog humanitarnog prava.

Nedržavni akteri u međunarodnom javnom pravu su svakako pozitivna pojava, sem u slučaju oružanih nedržavnih aktera koji učestvuju u oružanim sukobima. Opozicione oružane grupe se bore ili protiv zvaničnih administracija, odnosno vlada država i/ili jedni protiv 
drugih. Iako se pravni status takvih grupa vrlo često smatra sumnjivim, sa stanovišta međunarodnog prava sukobi u koje su oni uključeni najčešće zadržavaju nemeđunarodnu prirodu.

Praktična rešenja da se obezbedi implementacija normi međunarodnog humanitarnog prava mogu biti višestruka, ali čini se da bi formiranje mehanizma nadzora, u svim državama u kojima se odvija oružani sukob, bio najefikasniji. Taj mehanizam nadzora bi trebao da se zasniva na radu Ujedinjenih nacija, nevladinih organizacija koje se bave međunarodnim humanitarnim pravom, ali i ljudskim pravima. Organizacije za ljudska prava treba uključiti iz razloga što je i nakon okončanja neprijateljstava, ali i dok traje zamrznuti konflikt, neophodno nastaviti nadzor, posebno ako je nakon sukoba došlo do pokušaja formiranja odvojene teritorije, ili države koja još nije stekla svoj puni suverenitet već se nalazi $u$ pravnom vakuumu. Pravni vakuum podrazumeva neke formirane oblike vlasti, ali bez potpunog formiranja državnog sistema.

Praktična primena međunarodnog prava oružanih sukoba ukazuje da nisu iscrpljeni svi kapaciteti kako bi se obezbedilo poštovanje normi. Primetna je razlika u intenzitetu i doslednosti u naporima da se okončaju sukobi i obezbedi obnova države i državnog sistema u Sudanu, Avganistanu i Siriji. Čini se da je angažovanost međunarodne zajednice najviše uspeha postigla u sukobu u Siriji, a da je glavni razlog zainteresovanost Ruske Federacije da se što pre okonča sukob u Siriji i da se što pre otklone sve posledice oružanog sukoba.

Oružani sukobi u poslednjih trideset godina doživeli su transformaciju, posebno iz razloga narastajuće uloge nedržavnih aktera i entiteta u tim sukobima. Međunarodno pravo oružanih sukoba je u cilju praćenja postojeće situacije $u$ doktrinarnim i normativnim elementima dovelo do izvesnih izmena, a ono što će se tek menjati je praktična primena i izvesne promene $u$ tumačenju i primeni postojećeg međunarodnog prava oružanih sukoba. Humanitarna zaštita žrtava oružanih sukoba mora da nastavi da jača. Dalji razvoj humanizacije mora da se odvija nauštrb „vojne potrebe“. Na kraju, neophodno je da se pojača sistem kolektivne bezbednosti, da se ojača primena i poštovanje opšteg međunarodnog prava. 
Sagledavajući oružane sukobe u kojima su učesnici nedržavni akteri, upečatljivo je da je lista kršenja humanitarnog prava prilično velika. Međunarodna zajednica treba da preduzme sve napore da sva lica koja su odgovorna za najteža kršenja pravila međunarodnog prava oružanih sukoba budu izvedena pred pravosudna tela. Mnogi izveštaji ukazuju da još nisu preduzete sve mere u sanaciji svih posledica oružanih sukoba u kojima su učešće uzeli i nedržavni entiteti.

\section{LITERATURA}

Andrassy, Juraj, Bakotić, Božidar, Vukas, Budislav, Međunarodno pravo, Zagreb, 1989, str. 46-47.

Aston, Ben,"Critically assess Kaldor's assertion that new wars have to be understood in the context of the process known as globalization", Global Politics \& Violence, http://opendemocracy.net/debates/article -2-103-2294.jsp.benaston.com/.../Critically\%20assess\%20Kaldors;

Bartoš, Milan, Međunarodno javno pravo, knj. I, Beograd, 1954.

Bellal, Annyssa, Giacca, Gilles and Casey-Maslen, Stuart, "International law and armed non-state actors in Afghanistan", International Review of the Red Cross, Volume 93 Number 881 March 2011. p. 47, pp. 47-79.

Charls, Rhine, S., International Law, Washington, 1971, pp. 9-13.

Degan, Vladimir-Đuro, Međunarodno pravo, Rijeka, 2000, str. 33-35.

Detter, Ingrid, The Law of War, Cambridge University Press, 2nd ed., 2000, p. 5.

Dietrich, Schindler, "The Different Types of Armed Conflicts According to the Geneva Conventions and Protocols (Volume )", in: Collected Courses of the Hague Academy of International Law, 1979, Vol. 163, pp. 119-163.

Fallah, Katherine, "Corporate actors: the legal status of mercenaries in armed conflicts", International Review of the Red Cross, ICRC, Geneve, 2005.

Feldman, David, "International Personality“, in 191 Collected Courses Of The Hague Academy Of International Law, pp. 345, 358-359 (1985). 
Fergusson, James, Taliban: The True Story of the World's Most Feared Fighting Force, Bantam Press, London, 2010.

Heintze, Hans-Joachim, "Do Non-State Actors Challenge International Humanitarian Law?", In: von Heinegg W.H., Epping V. (eds.), International Humanitarian Law Facing New Challenges. Springer, Berlin, Heidelberg, 2007, p. 163.

Jončić, Miloš, „Savremene tendencije u razvoju međunarodnog humanitarnog prava", Savremeni međunarodni ekonomski i pravni poredak, ur. Sanja Jelisavac Trošić, Institut za međunarodnu politiku i privredu, Beograd, 2016, str. 260.

Jončić, Miloš, Međunarodnopravni položaj civilnog stanovništva u oružanim sukobima, Institut za međunarodnu politiku i privredu, Beograd, 2019.

Jončić, Vladan, „Značaj Berlinske rezolucije o primeni međunarodnog humanitarnog prava $u$ oružanim sukobima $u$ kojima učestvuju nedržavni entiteti“ , Pravni život, Udruženje pravnika Srbije, Beograd, 2013, knj. 12, str. 175-196.

Jončić, Vladan, Međunarodno humanitarno pravo, Beograd, 2015, str. 8.

Jončić, Vladan, Međunarodnopravni status učesnika oružanih sukoba, Pravni fakultet, Beograd, 2012.

Jončić Vladan, Međunarodnopravni status učesnika oružanih sukoba, Pravni fakultet, Beograd, 2012, str.118-129.

Jončić, Vladan: „Pravni smisao oružanih sukoba u procesu evropskih integracija", Srpska politička misao, Institut za političke studije, No. 1/2015, Vol. 47, Beograd, 2015, str. 193-207.

Kellenberger, Jakob, International Humanitarian Law at the Beginning of the 21st Century, Address to 26th Roundtable on Current Problems of International Humanitarian Law, San Remo, 5 September 2002. https://www.icrc.org/en/doc/resources/documents/statement/5 e2c8v.htm

Klauzevic, Karl fon, O ratu, VIZ, Beograd, 1951.

Obradović, Konstantin, (ured.), Humanitarno pravo: savremena teorija $i$ praksa", Beogradski centar za ljudska prava, Beograd, 1997.

Kreća, Milenko, Međunarodno javno pravo, Beograd, 2010. 
Krivokapić, Boris, „O nauci međunarodnog prava u antičkom svetu“, Pravni život, 12/ 2013, str. 215.

Krivokapić, Boris, Međunarodno javno pravo, Poslovni i pravni fakultet, Institut za uporedno pravo, Beograd, 2017, str. 46-59.

Krivokapić, Boris, Međunarodno pravo - Koreni, razvoj, perspektive, Megatrend univerzitet, Beograd, 2006.

Krivokapić, Boris, Mir i rat, Institut za uporedno pravo, Poslovni i pravni fakultet, Beograd, 2017, str. 72-76, 540-547.

Mchugh, Gerard \& Bessler, Manuel, Humanitarian Negotiations with Armed Groups: A Manual For Practitioners, and Guidelines on Humanitarian Negotiations With Armed Groups, United Nations Office for the Coordination of Humanitarian Affairs (OCHA) in collaboration with members of the Inter-Agency Standing Committee (IASC), 2006, p. 1.

Menon P. K., The Subjects of Modern International Law, 3 Hague Yearbook of International Law 3, 1990.

Moir, Lindsay, The Law of Internal Armed Conflict, Cambridge University Press, Cambrige, 2004, p. 4.

Naj, Džozef S. Jr., Kako razumevati međunarodne sukobe, Stubovi kulture, Beograd, 2006, str. 16-17.

Oppenheim, L., International Law, War and Neutrality, 7th edn, ed. H. Lauterpacht, London, 1952.

Portmann, Roland, Legal Personality in International Law (Cambridge Studies in International and Comparative Law), Cambridge University Press, Cambridge, 2010, pp. 42-79.

Preuzeto iz Vladan Jončić, „Značaj Berlinske rezolucije o primeni međunarodnog humanitarnog prava u oružanim sukobima u kojima učestvuju nedržavni entiteti“ , Pravni život, Udruženje pravnika Srbije, Beograd, 2013, br. 12, knj. 566, str. 175-196.

Radivojević, Zoran, Knežević Predić, Vesna, „Prag primene međunarodnog humanitarnog prava“, Teme, g. XXXVII Br. 1, januarmart 2013, Niš, str. 383-403. 
Radojković, Stefan, „Nedržavni akteri i praksa zagovaranja nezavisnosti - slučaj Kosova od 1999. do 2008. godine“, Godišnjak Fakulteta Političkih Nauka, Beograd, Jun, 2016, Vol. 10 Issue 15, str. 135-160.

Rodenhäuser, Tilman, "International legal obligations of armed opposition groups in Syria", Jurnal of International Review of Law, Qatar University, Vol . 2015 No. 1, 2015, p. 1-16.

Schwarzenberger, Georg, International Law, the Law of armed conflictt, International law as applied by international courts and tribunals, Stevens, London, 1957.

Seyersted, Finn, United Nations Forces in the Law of Peace and War, Leyden, 1966, pp. 299-304; Blix, H., "Contemporary Aspects of Recognition”, 130 Recueil des cours, 1970, Vol. II, pp. 615-619.

Smith, Michael, "Guerillas in the mist: reassessing strategy and low intensity warfare", Review of International Studies, 2003, pp. 35-37.

Trapara, Vladimir, Jončić, Miloš: „Put za rešavanje sukoba - uporedna analiza zamrznutih sukoba na prostoru OEBS", Međunarodni problemi, Institut za međunarodnu politiku i privredu, godina LXIV br. 2, 2012, str. 275-302.

Tunkin, G. I., Meždunarodnoe pravo, Moskva, 1982, str. 14-15.

Van Creveld, Martin, The Transformation of War, The Free Press, New York, 1991.

Vučinić, Zoran, Međunarodno ratno i humanitarno pravo, Službeni glasnik, Beograd, 2006.

Vučinić, Zoran, Međunarodno ratno i humanitarno pravo, Vojnoizdavački zavod, Beograd, 2001.

William, T. Worster, "Relative International Legal Personality of NonState Actors", Brooklyn Journal of International Law, (2016). Vol. 42, p. 207, Available at: https:/ / brooklynworks.brooklaw.edu/bjil/vol42/ iss1/4

Dokumenta:

"Agreement on the Civilian Protection Component of the International Monitoring Team (IMT)", United Nations, 27/10/2009, Article 1, 
dstupno na: https:/ / peacemaker.un.org/sites/peacemaker.un.org/ files/PH_091027_Agreement\%20on\%20Civilian\%20Protection \%20C omponent.pdf

"International Crisis Group, 'Taliban propaganda: winning the war of words?'", Dostupno na: https://www.crisisgroup.org/asia/southasia/afghanistan/taliban-propaganda-winning-war-words

"PKK Statement To The United Nations", Geneva, 24 January, 1995, dostupno na: http:/ / www.hartford-hwp.com/archives/51/009.html

"Protocol Between the Government of the Sudan, Sudan Liberation Movement/Army and the Justice and Equality Movement on the Improvement of the Humanitarian Situation in Darfur", United Nations, Nov. 9, 2004.

"Resolution adopted by the Human Rights Council, The Human Rights Situation in Iraq in the light of abuses committed by the socalled Islamic State in Iraq and the Levant and associated groups", Human Rights Council, Twenty-second special session, A/HRCC/ RES/S-22/1.

„Dopunski protokol uz Ženevske konvencije od 12. avgusta 1949. godine o zaštiti žrtava međunarodnih oružanih sukoba (Protokol I) ", Izvori međunarodnog humanitarnog prava, Jugoslovenski crveni krst, Beograd, 1999.

„First Report of The Committee, Non-State Actors In International Law: Aims, Approach and Scope of Project and Legal Issues", International Law Association, The Hague Conference (2010), International Law Association Reports on Conferences.

„The Application of International Humanitarian Law and Fundamental Human Rights", in Armed Conflicts in which Non-State Entities are Parties, The Institute of International Law, Session of Berlin, 1999.

"Yearbook of the Institut of International Law", 68-I, 1999.

„Ženevska konvencija o zaštiti Građanskih lica za vreme rata od 12. avgusta 1949. (IV Ženevska konvencija)“, Izvori međunarodnog humanitarnog prava, Jugoslovenski crveni krst, Beograd, 1999. 
"Ženevske Konvencije o zaštiti žrtava rata od 1949. godine“, Izvori međunarodnog humanitarnog prava, Jugoslovenski crveni krst, Beograd, 1999.

Slučaj „Faludža, ("Bodies mutilated in Fallujah attack”, BBS News (UK), 31 March 2004, available at http:/news.bbc.co.uk/2/hi/middle _east/3585765.stm

The Yearbook of the Institute of International Law , Centenary Session , Roma, 1973, Vol. 55, pp. 515-516.

The Yearbook of the Institute of International Law, 68-I, 1999, pp. 263, 329. 


\section{NON-STATE ACTORS IN INTERNATIONAL HUMANITARIAN LAW}

Abstract: The existence of non-state actors, as subjects in international relations and as parties in armed conflicts, have an increasing influence in the international community and the field of international law. The most common question that arises from the standpoint of doctrine and practice of international law concerns their status, precisely their international rights and obligations, responsibility for violating the norms of international public law, and especially international law of armed conflict (international humanitarian law). The issue of recognizing and increasing their legal subjectivity is the subject of this paper. Also, the subject of the research is to determine to what extent and on what legal basis the norms of international humanitarian law are applied and oblige non-state actors. As non-state actors (conditionally non-state entities) cannot formally become parties to international treaties governing protection in armed conflicts, the issue of alternative mechanisms by which these actors can express their consent and commit to compliance with international law is considered in general, especially international humanitarian law. Each of these alternative mechanisms provides an opportunity to establish liability for the violations of the rules of international law. The paper analyzes the concept and legal position of non-state actors as participants in armed conflicts. Non-state entities may be participants in non-international armed conflicts. However, the altered character of armed conflicts in the late 20th and early 21st centuries has erased a clear line between international and non-international armed conflicts and left doubt as to whether non-state entities can be parties to armed conflicts characterized as mixed or internationalized. The aim of this paper is to find relevant answers related to non-state entities and actors in international law, based on the research of the changed character of armed conflicts and the position of non-state actors and entities in them. A particular problem is a fact that some non-state actors, as participants in armed conflicts, do not have the status of a legal participant, which significantly complicates the application of international legal norms.

Keywords: non-state actors, non-state entities, armed conflicts, legal participants in armed conflict, international law of armed conflicts. 